\title{
Phytoestrogens' beneficial effects on cardiovascular system
}

\author{
Jeanne Adiwinata Pawitan
}

\begin{abstract}
Abstrak
Berbagai bukti yang didapat dari hasil penelitian epidemiologi, uji klinik, dan penelitian ilmu dasar menunjukkan kemungkinan adanya hubungan kausal terbalik antara konsumsi fitoestrogen dan penyakit kardiovaskular. Fitoestrogen adalah bahan alami yang didapat dari tumbuh-tumbuhan, dan mempunyai struktur kimia mirip estrogen, yaitu struktur 2-fenilnaftalen. Fitoestrogen terbagi atas 3 kelas, yaitu isoflavon, lignan, dan coumestan. Kebanyakan fitoestrogen yang terdapat dalam makanan manusia adalah isoflavon, dan lignan. Saripustaka ini merangkum berbagai hal tentang fitoestrogen, terutama isoflavon, mulai dari bahan makanan yang mengandung fitoestrogen dan 'bioavailibility'nya, sampai berbagai efek fitoestrogen yang menguntungkan sistem kardiovaskular, yaitu pada atherosklerosis, hiperkolesterolemia, elastisitas arteri, dan tekanan darah. (Med J Indones 2002; 11: 120-3)
\end{abstract}

\begin{abstract}
Several lines of evidence, including epidemiological, clinical trial and basic science, suggest the plausibility of a causal, inverse relationship between phytoestrogens and cardiovascular disease. Phytoestrogens are naturally occurring plant compounds that have 2-phenylnaphthalene-type chemical structures similar to those of estrogens. They are simply divided into three main classes, isoflavones, lignans, and coumestans. The majority of phytoestrogens found in typical human diets are the isoflavones and lignans. This review provides an overview of the potential sources and bio-availability of phytoestrogens particularly isoftavones, and discusses their beneficial effects on cardiovascular system, i.e. on atherosclerosis, hypercholesterolemia, arterial compliance, and blood pressure. (Med J Indones 2002; 11: 120-3)
\end{abstract}

Keywords: atherosclerosis, hypercholesterolemia, arterial compliance, blood pressure

Several lines of evidence, including epidemiological, clinical trial and basic science, suggest the plausibility of a causal, inverse relationship between phytoestrogens and cardiovascular disease. The well establish low rates of cardiovascular diseases and the high intakes of dietary phytoestrogens in Asian populations relative to those in other industrialized countries are consistent with the potential protective effect of phytoestrogens. ${ }^{1-3}$

Phytoestrogens are naturally occurring plant compounds that have 2-phenylnaphthalene-type chemical structures similar to those of estrogens. 'They are found in many human foodstuffs including beans, grains, green vegetables, fruits, and nuts. ${ }^{4}$

Phytoestrogens are flavonoids broadly grouped into 4 main classes, isoflavones, lignans, coumestans, and resorcyclic lactones. The three first mentioned are

Department of Histology, Faculty of Medicine, University of Indonesia, Jakarta, Indonesia found in human diets, while resorcyclic lactones are mycotoxins that develop in stored crops. Therefore they are not true phytoestrogens, and phytoestrogens can be simply divided into 3 classes. ${ }^{5}$ The majority of phytoestrogens found in typical human diets are the isoflavones and lignans, while the major phytoestrogen consumed by most Asian populations is isoflavones.'

This review provides an overview of the potential sources and bio-availability of phytoestrogens particularly isoflavones, and discusses their potential use to prevent cardiovascular diseases.

\section{POTENTIAL SOURCES OF ISOFLAVONES}

The major sources of isoflavones in Asian diet are soy and its products. The primary isoflavones in soybeans are genistein, daidzein, and their respective $\beta$-glycosides (genistin and daidzin). In addition, much lower amounts of glycitein and its glycoside (glycitin) are present in soybeans. ${ }^{6}$ Humans consume soybeans and their products in many forms, including whole soybeans, tempeh, tofu, 
and soy milk. The concentrations of isoflavons in its major sources are showed in Table 1.

Table 1. The potential sources of isoflavons

\begin{tabular}{ll}
\hline Source & Concentration $(\mu \mathrm{g} / \mathrm{g})$ \\
\hline Soybean & $1,176-4,215^{*}$ \\
Roasted soybean & 2,661 \\
Soy flour & 2,014 \\
Soy granule & 2,404 \\
Textured vegetable proteins & $2,261-2,295^{*}$ \\
Protein isolate & $621-987^{*}$ \\
Tofu & $260-532^{*}$ \\
Tempeh & 865 \\
Miso & $389-647^{*}$ \\
\hline
\end{tabular}

Modified from Tham et al, 1998

* More than one lot were assayed

\section{BIOAVAILABILITY OF ISOFLAVONE PHYTOESTROGENS}

Phytoestrogens in plants are different from that found in humans and animals. To be absorbed they should be fermented/metabolized by gut microflora. In plants, some isoflavons are bound to sugar residue to form glycosides, which are inactive. When the sugar residue is removed, the glycoside form becomes active compounds. ${ }^{1,6}$ In plants, both the glycoside and aglycon forms are present. ${ }^{1}$ In humans, isoflavone aglycones are absorb faster and in greater amounts than their glycosides. ${ }^{7}$ The conversion process from plant isoflavones to human isoflavons detected in blood and urine is showed in Figure 1.
Once ingested, several factors influence the bioavailability of isoflavones, i.e. intestinal degradation by colonic microflora and the presence of fiber in the diet, which correlate positively with absorption.'

\section{THE POTENSIAL USE OF PHYTOESTROGENS TO PREVENT CARDIOVASCULAR DISEASES}

\section{Epidemiological studies}

Epidemiological studies revealed low rates of cardiovascular diseases among Asian populations whose diets were rich in phytoestrogens, relative to those in Western countries. This evidence suggests a plausible causal inverse relationship between phytoestrogens and cardiovascular disease. However, this association is confounded by other concomitant dietary differences, making it difficult to attribute the low rates of cardiovascular diseases to phytoestrogen intake. ${ }^{l}$ Furthermore, the major source of phytoestrogens in Asian diets are soy and its products, that contain cholesterol lowering agents, such as $\alpha$-linolenic acid and saponins. Therefore, the low rates of cardiovascular diseases among Asian populations might be attributed to those agents, though the hypocholesterolemic effects of saponins in humans are still speculative. ${ }^{6}$

To assess the potential use of phytoestrogens to prevent cardiovascular diseases, several studies were conducted. Among those studies, a cross sectional study showed that dietary isoflavone intake was associated with reduced cardiovascular disease risk in postmenopausal women. In this study's adjusted

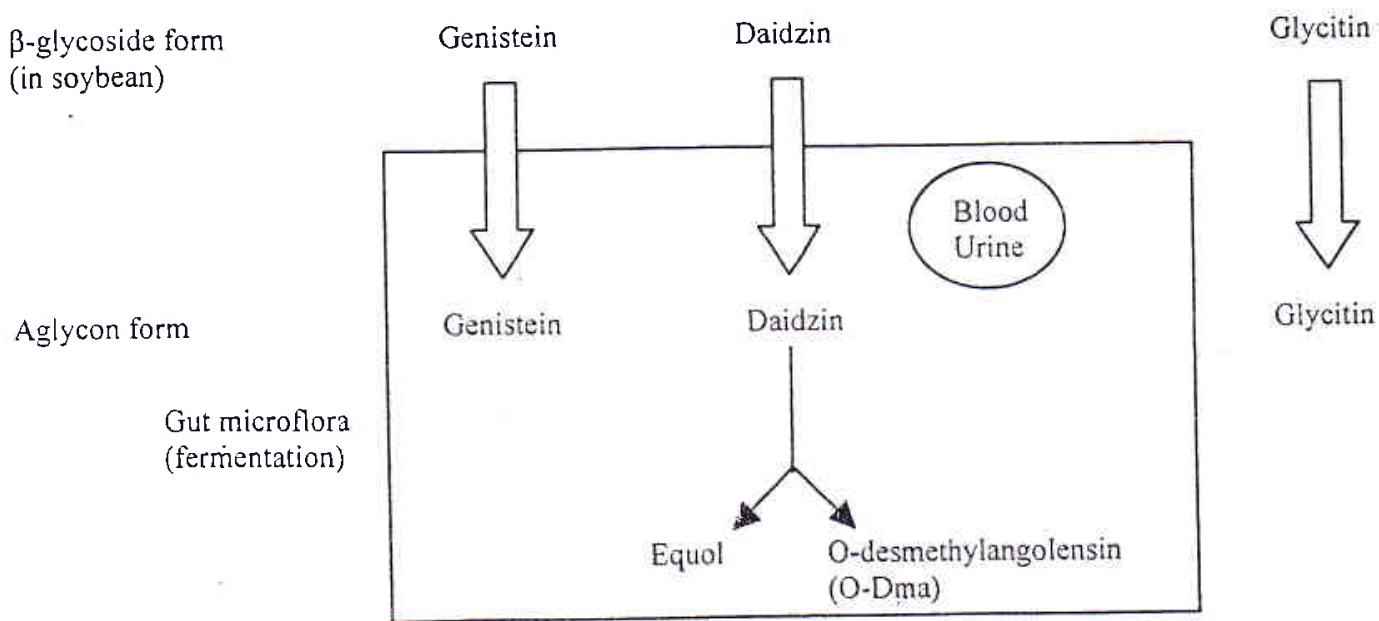

Figure 1. The conversion of plant isoflavones to human isoflavones 
analyses, genistein, daidzein, and total isoflavone intake were each positively associated with HDL cholesterol and inversely associated with post challenge insulin. ${ }^{8}$

\section{Intervention study}

An intervention study suggested a cardioprotective role for supplemental phytoestrogen (isoflavone). In this study, supplementation of $34 \mathrm{mg}$ phytoestrogens for 6 weeks showed improvements in lipid and lipoprotein level, and blood pressure.'

\section{MECHANISMS FOR THE CARDIOVASCULAR PROTECTIVE EFFECTS OF PHYTOESTROGENS}

The mechanisms for the cardiovascular protective effect of phytoestrogens are shown by several studies.

\section{Phytoestrogens' effect on atherosclerosis}

A study showed that isoflavone phytoestrogens reduced lipid peroxidation in vivo and increased the resistance of low-density lipoprotein (LDL) to oxidation. Isoflavones (genistein, daidzein and equol) were also shown as antioxidants in vitro. These facts may be a significant mechanism in reducing the risk of atherosclerosis and cardiovascular disease. ${ }^{10}$

Furthermore, various studies have suggested that genistein acts as a protein tyrosine kinase inhibitor. An increase in tyrosine phosphorylation at tyrosine residues of platelet proteins is associated with thrombin-induced platelet's activation. Therefore, genistein as a tyrosine kinase inhibitor is though to be responsible for a reduction in the deposition and aggregation of platelets, and a decrease in the progression of atherosclerosis. This thought is however opposed by other workers who observed that concentrations of genistein up to
$100 \mu \mathrm{g} / \mathrm{mL}$ had no significant effect on thrombininduced platelet activation. On the other hand those workers demonstrated that daidzein, which has no inhibitory activity for tyrosine kinase, and also genistein were able to suppress platelet responses elicited by both collagen and thromboxane $\mathrm{A} 2$. $^{11}$

However, the thought that genistein and daidzein could suppress platelet activation was opposed by a clinical trial involving $60 \mathrm{~g} /$ day of a soy protein isolate beverage powder for 28 days, that showed a dramatic rise in plasma isoflavone concentrations, detected no significant effect on platelet aggregation. ${ }^{12}$ Therefore, more studies will need to be conducted to clarify the exact mechanism by which phytoestrogens affect various platelet responses. ${ }^{1}$

\section{Phytoestrogens' hypocholesterolemic effect}

Several human clinical trials with phytoestrogens have reported inconsistent serum lipid effects, ${ }^{1}$ with a bigger tendency to favorable effects. The dose needed to get a hypocholesterolemic effect is shown in Table 2.

The mechanisms for the hypocholesterolemic effect of soy phytoestrogens are supposed to be due to the upregulation of $\mathrm{LDL}$ receptors and/or inhibition of endogenous cholesterol synthesis. ${ }^{13}$ This may be of particular significance for hyperlipidemics. Lignans may also affect cholesterol homeostasis, as they have been shown to inhibit the activity of cholesterol- $7 \alpha$ hydroxylase, the rate-limiting enzyme in the formation of primary bile acids from cholesterol. ${ }^{1}$

\section{Phytoestrogens' effects on arteries}

Soy phytoestrogens favorably influence coronary reactivity. In a study on the effect of phytoestrogens (genistein, phloretin, biochanin A and zearalanone) on isolated rabbit coronary artery rings showed that genistein, phloretin and biochanin A induced

Table 2. The dosage needed to get beneficial effect in various condition

\begin{tabular}{|c|c|c|c|}
\hline Subject & Phytoestrogens & Dose/duration & Improvement \\
\hline Perimenopausal women & $\begin{array}{l}\text { Phytoestrogens in soy } \\
\text { protein }\end{array}$ & $\begin{array}{l}34 \mathrm{mg} \text { in single dose or split into } \\
2 \text { doses for } 6 \text { weeks }\end{array}$ & $\begin{array}{l}\text { Lipid and lipoprotein level, blood } \\
\text { pressure }^{8}\end{array}$ \\
\hline $\begin{array}{l}\text { Healthy, normo- } \\
\text { cholesterolemic, } \\
\text { premenopausal women }\end{array}$ & $\begin{array}{l}\text { Conjugated isoflavones in } \\
\text { soy product }\end{array}$ & $45 \mathrm{mg} /$ day & Total cholesterol ${ }^{l}$ \\
\hline
\end{tabular}


significant gender-independent relaxation in rings with and without endothelium. This study demonstrated that phytoestrogens induce endothelium-independent relaxation of coronary arteries. ${ }^{14,15}$ A placebocontrolled crossover trial tested the effects of phytoestrogens in the form of soy-isoflavones in peri- and post-menopausal women, and found that the systemic arterial compliance (arterial elasticity) was significantly improved in those taking soyisoflavones. ${ }^{16}$ Phytoestrogens also inhibit the progression of atherosclerosis in the coronary, iliac and common carotid arteries. The cardiovascular benefits of soy phytoestrogens appear to be equal for males and females. ${ }^{14}$

In another study on human aortic smooth muscle cells (SMC), phytoestrogens may confer protective effects on the cardiovascular system by inhibiting vascular remodeling and neointima formation.

In conclusion, phytoestrogens are strongly believed to have a potential role in the reduction of cardiovascular disease. The mechanisms of actions might be through blood pressure reduction, inhibition of lipid peroxidation and platelet aggregation, thus preventing atherosclerosis, increasing arterial compliance and/or hypocholesterolemic effect.

\section{REFERENCES}

1. Tham DM, gardner CD, Haskel WL. Potential health benefits of dietary phytoestrogens: a review of the clinical, epidemiological, and mechanistic evidence. J Clin Endocrinol Metab 1998;83(7):2223-35.

2. Artaud-Wild SM, Connor SL, Sexton J, Connor WE. Differences in coronary mortality can be explained by differences in cholesterol and saturated fat intakes in 40 countries but not in France and Finland. A paradox. Circulation 1993;88:2271-9.

3. Keys A, Menotti A, Aravanis C, et al. The seven countries study: 2,289 deaths in 15 years. Prev Med 1984;13:141-54.

4. van der Schouw YT, de Klein MJ, Peeters PH, Grobbee DE. Phyto-oestrogens and cardiovascular disease risk. Nutr Metab Cardiovasc Dis 2000;10(3):154-67.
5. Wildman REC, Medeiros DM. Nutrition supplement and nutraceuticals. In: Wildman REC, Medeiros DM. Advanced human Nutrition. Boca Raton: CRC Press; 2000. p. 367-398.

6. Messina MJ. Legumes and soybeans: overview of their nutritional profiles and health effects. Am J Clin Nutr 1999;70(suppl):439S-50S.

7. Izumi T, Piskula MK, Osawa S, Obata A, Tobe K, Saito $\mathrm{M}$, et al. Soy isoflavone aglycones are absorbed faster and in higher amounts than their glucosides in humans. J Nutr 2000;130:1695-9.

8. Goodman-Gruen D. Kritz-Silverstein D. Usual dietary isoflavone intake is associated with cardiovascular disease risk factors in postmenopausal women. J Nutr 2001; 131:1202-1206.

9. Washburn S, Burke GL, Morgan T, Anthony M. Effect of soy protein supplementation on serum lipoprotein, blood pressure, and menopausal symptoms in perimenopausal women. Menopause 1999;6(1):7-13.

10. Wiseman $\mathrm{H}$, O'Reilly JD, Adlercreutz $\mathrm{H}$, Mallet AI, Bowey EA, Rowland IR. Isoflavone phytoestrogens consumed in soy decrease F2-isoprostane concentrations and increase reșistance of low-density lipoprotein to oxidation in human. Am J Clin Nutr 2000;72(2):395-400.

11. Nakashima S, Koike T, Nozawa Y. Genistein, a protein tyrosine kinase inhibitor, inhibits thromboxane A2- mdiated human platelet responses. Mol Pharmacol 1990;39:475-80.

12. Gooderham MJ, Adlercreutz $\mathrm{H}$, Ojala ST, Wahala $\mathrm{K}$, Holub BJ. A soy protein isolate rich in genistein and daidzein and its effect on plasma isoflavone concentration, platelet aggregation, blood lipids and fatty acid composition of plasma phospholipid in normal men. J Nutr 1996; 126:2000-6.

13. Sirtori CR, Lovati MR, Manzoni C, Monetti M, Pazzuconi F, Gatti E. Soy and cholesterol reduction: clinical experience. J Nutr 1995;125(Suppl):598S-605S.

14. Clarkson TB, Anthony MS. Phytoestrogens and coronary heart disease. Baillieres Clin Endocrinol Metab 1998; 12:589-604.

15. Figtree GA, Griffiths H, Lu YQ, Webb CM, Macleod K, Collins P. Plant-derived estrogens relax coronary arteries in-vitro by a calcium antagonistic mechanism. J Am Coll Cardiol 2000;35:1977-85.

16. Nestel PJ, Yamashita T, Sasahara T, Pomeroy S, Dart A, Komesaroff $P$, et al. Soy isoflavones improve systemic arterial compliance but not plasma lipids in menopausal and perimenopausal women. Arteriosclerosis 1997;17 3392-8. 